\title{
PROSEDUR ADMINISTRASI JASA PENGIRIMAN BARANG DI PT CITRA VAN TITIPAN KILAT TANGERANG
}

\author{
Desilia Purnama Dewi ${ }^{1}$ \\ Dosen Prodi D-III Sekreteri Universitas Pamulang \\ Desiliadewi3@gmail.com \\ Harjoyo $^{2}$ \\ Dosen Prodi D-III Sekreteri Universitas Pamulang \\ harjoyo@yuasabattery.co.id \\ Abdul Salam ${ }^{3}$ \\ Mahasiswa Prodi D-III Sekretari Universitas Pamulang \\ Salam.abdul123@gmail.com
}

\begin{abstract}
ABSTRAK-Dalam pengembangan perusahaan komersial saat ini, mendorong pengusaha untuk mendistribusikan produk mereka kepada konsumen, yang perlu menyediakan persediaan dalam distribusi produk mereka, terutama perusahaan jasa yang terlibat dalam layanan logistik atau pengirirman barang. Selain itu, saat ini didukung oleh dunia internet yang telah menjadi bagian terpenting dari kehidupan banyak orang, demikian juga pertumbuhan pesat perusahaan yang ditawarkan oleh dunia online, seperti manufaktur dan ritel. Hal ini memicu pertumbuhan jasa kurir atau logistik di mana-mana, tanpa kehadiran layanan kurir, pengembangan perdagangan tidak memungkinkan untuk terus berkembang. Tujuan dari penelitian ini adalah: untuk mengetahui bagaimana prosedur administrasi jasa pengiriman barang di PT Citra Van Titipan Kilat Tangerang dan untuk mengetahui kendala-kendala yang sering dialami dalam menjalankan prosedur administrasi jasa pengiriman barang di PT Citra. Van Titipan Kilat Tangerang Teknik pengumpulan data melalui Pendataan yang dilakukan dengan cara terjun langsung dan pengumpulan data-data yang dilakukan dengan cara mempelajari berbagai macam bahan tertulis. Standar operasional prosedur (SOP) untuk surat berharga harus diasuransikan dan juga untuk produk elektronik juga harus diasuransikan dan menerima pengemasan kayu. Kendala yang biasanya terjadi dalam menjalankan prosedur administrasi jasa pengiriman barang di PT TIKI Tangerang adalah ada beberapa konsumen yang tidak terlalu terbuka dengan konten pengiriman, adanya hari libur nasional sehingga terjadi keterlambatan pengiriman, resi yang hilang, dan musibah alam. Secara keseluruhan kualitas administrasi umum yang diberikan kepada konsumen tidak diragukan lagi sangat bagus. Namun, PT TIKI Tangerang perlu ditingkatkan lagi mengenai kualitas dari pengiriman, yaitu: keandalan (reliability).
\end{abstract}

Kata Kunci: Administrasi, Jasa, Pengiriman Barang

\begin{abstract}
In the development of commercial businesses today, entrepreneurs are encouraged to distribute their products to consumers and need inventory to distribute their products, especially service companies involved in logistics services or product shipments. In addition, currently supported by the world of the internet, which has become the most important part of the lives of many people, as well as the rapid growth of companies offered throughout the world online, such as manufacturing and retail. the growth of courier or logistics services everywhere, without the presence of courier services, the development of trade makes it impossible to continue to grow. The purpose of this study is: to find out how the administrative procedures for freight forwarding services at PT Citra Van Titipan Kilat Tangerang and to find out the constraints that are often experienced in carrying out administrative procedures for freight forwarding services at PT Citra. Van Titipan Kilat Tangerang The technique of collecting data through data collection is done by plunging directly and collecting data carried out by studying various written materials. Standard Operating Procedures (SOP) applied in companies are for securities to be insured and also for electronic products must be insured and given wooden packaging.
\end{abstract}


Constraints that are common in carrying out administrative procedures for shipping services at PT TIKI Tangerang are that consumers are not too open to the contents of the shipment, there is a national holiday so that delivery delays occur, lost receipts, and natural disasters. Overall, the quality of administration provided by PT TIKI Tangerang to consumers is very good. However, there are several points that must be improved by PT TIKI Tangerang in terms of shipping quality, namely realability.

Keywords: Administration, Services, Goods Delivery

\section{PENDAHULUAN}

\section{Latar Belakang Masalah}

Dalam era globalisasi yang semakin berkembang, promosi penjualan barang dagangan dilakukan secara elektronik, berdasarkan jaringan internet dan jejaring sosial, di mana para konsumen dapat dengan mudah untuk mendapatkan berbagai macam informasi tentang barang yang akan dibeli dan para konsumen juga tidak perlu menghabiskan lebih banyak waktu dalam melakukan pembelian barang, karena pembelian dan penjualan barang dapat dengan mudah dilakukan di mana saja, tanpa adanya pertemuan langsung/tatap muka, ini menghasilkan minat publik yang semakin besar dalam pembelian barang dagangan dengan difasilitasi oleh berbagai mitra bisnis melalui layanan pengirimn barang sehingga memudahkan proses pengiriman barang dagangan ke konsumen.

Sejalan dengan tren ini, para penjual biasanya membutuhkan mitra bisnis yang memiliki layanan yang sangat baik dan konsisten di bidang pengiriman dan jasa, sehingga mendorong pengembangan komersial di bidang jasa pengiriman dan logistik. Hampir di setiap kota yang berada di Indoesia masyarakat sangat dengan mudah menemukan perusahaan angkutan kargo.

Ketika memilih perusahaan pengirirman barang, para konsumen biasanya sering mempertimbangkan beberapa hal, diantaranya yang menjadi prioritas adalah memilih perusahaan pengiriman barang dengan kantor yang jelas. Perusahaanperusahaan pengiriman barang bisanya juga memiliki mitra bisnis, seperti layanan kargo, kapal kargo dan pesawat kargo, dan umumnya berurusan dengan pejabat bandara dan bea cukai, termasuk menangani suratsurat penting.

Di masa globalisasi yang semakin meningkat, penjualan barang dipromosikan secara elektronik dan didasarkan pada Internet dan jejaring sosial, di mana konsumen dapat lebih mudah menemukan berbagai macam informasi-informasi yang berhubungan dengan produk yang akan dibelinya, kini para konsumen tidak perlu lagi membutuhkan waktu yang banyak untuk membeli produk. Karena proses pembelian dan penjualan dapat dilakukan di mana saja tanpa pertemuan/tatap muka, ini 
menghasilkan minat publik yang semakin besar dalam pembelian suatu barang, yang kemudian didukung oleh beberapa mitra komersial dalam jasa pengiriman barang sehingga memudahkan kegiatan pengiriman barang ke konsumen. Dengan demikian para penjual memerlukan rekan/mitra bisnis yang konsisten dalam menawarkan layanan dan pengiriman yang sangat baik. Biasanya konsumen sering mempertimbangkan beberapa aspek dalam memilih perusahaan pengiriman, pilihan perusahaan pelayaran dengan kantor yang jelas lebih diutamakan. Agen pengiriman umumnya memiliki mitra bisnis, seperti layanan kargo, kapal kargo dan pesawat kargo, dan umumnya berurusan dengan pejabat bandara dan bea cukai, termasuk menangani dokumen penting. Yang menjadi salah satu ukuran peringkat kepuasan pelanggan yaitu didapatnya layanan pengiriman berkualitas baik dengan membandingkan harapan dan kenyataan yang mereka terima.

Dalam pengembangan perusahaan komersial saat ini, mendorong pengusaha untuk mendistribusikan produk mereka kepada konsumen, yang perlu menyediakan persediaan dalam distribusi produk mereka, terutama perusahaan jasa yang terlibat dalam layanan logistik atau pengirirman barang. Selain itu, saat ini didukung oleh dunia internet yang telah menjadi bagian terpenting dari kehidupan banyak orang, demikian juga pertumbuhan pesat perusahaan yang ditawarkan oleh dunia online, seperti manufaktur dan ritel. Hal ini memicu pertumbuhan jasa kurir atau logistik di manamana, tanpa kehadiran layanan kurir, pengembangan perdagangan tidak memungkinkan untuk terus berkembang.

Kegiatan distribusi, dalam hal ini, PT TIKI Tangerang harus dikelola dengan sistem yang baik dan profesional, untuk menghasilkan layanan yang sangat baik, tujuan dari layanan yang sangat baik ini diterapkan untuk pengiriman nasional dan internasional untuk selalu menawarkan layanan yang memuaskan kepada pengguna layanan . Dengan hadirnya pelayanan prima PT TIKI Tangerang, kehidupan masyarakat akan meningkat dan mudah dalam melakukan pengiriman barang baik untuk tujuan domestik maupun luar negeri, dengan menggunakan layanan yang tersedia: One night service, regular service ataupun someday service yang merupakan layanan pengiriman cepat dengan harga terjangkau.

Dengan perkembangan perusahaan ritel saat ini, pengusaha didorong untuk menjual produk mereka kepada konsumen yang perlu menyediakan inventaris saat mendistribusikan produk mereka, terutama kepada perusahaan jasa yang terlibat dalam layanan logistik atau pengiriman barang. Selain itu, saat ini kompatibel dengan dunia internet, yang telah menjadi bagian terpenting 
dari kehidupan banyak orang, dan dengan pertumbuhan cepat perusahaan yang ditawarkan oleh dunia online, seperti manufaktur dan ritel. Hal ini memicu pertumbuhan layanan kurir atau logistik di mana-mana, tanpa kehadiran layanan kurir, tidak mungkin ada pengembangan perdagangan lebih lanjut.

Kegiatan penjualan, dalam hal ini PT TIKI Tangerang, harus dikelola dengan sistem yang baik dan profesional untuk memberikan layanan prima. Tujuan dari layanan yang sangat baik ini adalah untuk menerapkan pengiriman nasional dan internasional untuk selalu memberikan layanan yang memuaskan bagi pengguna layanan. Berkat layanan prima PT TIKI Tangerang, kehidupan masyarakat akan meningkat dan akan mudah untuk mengirimkan produk ke tujuan domestik dan luar negeri ketika menggunakan layanan yang tersedia: One night service, regular service ataupun someday service yang merupakan layanan pengiriman cepat dengan harga terjangkau.

Ini menunjukkan bahwa proses layanan transportasi PT TIKI Tangerang yang sangat baik dapat digunakan sebagai tim yang mampu bekerja lebih cepat dengan jaminan bahwa jika pemrosesan dan distribusi lancar, pengiriman barang ke tujuan akan tepat waktu, jika tidak, jika proses pengolahan dan distribusi data tidak berjalan dengan lancar, pengiriman produk ke tujuan akan terlambat.

Kepuasan pelanggan adalah point penting yang terkait erat dengan kepuasan pembelian di perusahaan yang beroperasi di sektor jasa. Secara umum biasanya jika pelanggan puas dengan produk atau layanan yang diberikan, ia akan melakukan pembelian berulang dan menambah jumlah pembelian. Kemudian, pelanggan yang puas juga dapat memberi tahu orang lain tentang pengalaman yang menguntungkan, menghasilkan informasi positif dari mulut ke mulut, untuk secara tidak langsung meningkatkan pangsa pasar perusahaan.

Kepuasan pelanggan merupakan kata kunci dalam memenangkan persaingan, sehingga setiap perusahaan berkepentingan untuk memenuhi segala aspek tersebut. Berdasarkan latar belakang diatas maka penulis melakukan penelitian dengan judul "Prosedur Administrasi Jasa Pengiriman Barang Di PT Citra Van Titipan Kilat Tangerang"

\section{Perumusan Masalah}

Adapun perumusan masalah dari penelitian ini adalah :

1. Bagaimana prosedur administrasi jasa pengiriman barang di PT Citra Van Titipan Kilat Tangerang?

2. Kendala-kendala apa saja yang sering dialami dalam menjalankan prosedur administrasi jasa pengiriman barang pada PT Citra Van Titipan Kilat Tangerang? 
Tujuan dari penelitian ini adalah:

1. Untuk mengetahui bagaimana prosedur administrasi jasa pengiriman barang di PT Citra Van Titipan Kilat Tangerang.

2. Untuk mengetahui kendala-kendala yang sering dialami dalam menjalankan prosedur administrasi jasa pengiriman barang di PT Citra Van Titipan Kilat Tangerang.

\section{Metode Penelitian}

Penulis membutuhkan data yang terkait dengan studi penulis tentang:

\section{Jenis data}

1. Data Primer

Data primer adalah sumber data yang dikumpulkan oleh penulis, yang penulis dapat secara langsung

2. Data Sekunder

Data sekunder adalah sumber data yang digunakan oleh penulis melalui sarana perantara atau tidak langsung, dalam bentuk buku, situs web, dan arsip dalam file.

\section{Teknik pengumpulan data}

1. Data primer

Sumber data dengan melalui terjun langsung kelapangan, yang dilakukan di PT TIKI Tangerang sebagai objek studi.

2. Data sekunder

Sumber data dilakukan dengan mempelajari berbagai bahan atau kajian tertulis, seperti membaca buku untuk mendukung penelitian, serta catatan dan referensi tertulis lainnya yang berkaitan dengan prosedur administrasi pengiriman barang di PT Tiki Tangerang.

\section{LANDASAN TEORI}

\section{Pengertian Administrasi}

Istilah administrasi berasal dari kata Latin "ad + Minister", yang memiliki pemahaman dalam bahasa Indonesia: bantuan, layanan, dan kepatuhan (kata sifat administratius, dan kata bendanya (adminitratio). Berikut ini beberapa pengertian dari administrasi:

Menurut perumusan Ordway-Tead, administrasi mencakup kegiatan yang harus dilakukan oleh eksekutif dalam organisasi yang perannya adalah mengatur, mempromosikan, dan menyelesaikan upaya kolaboratif sekelompok orang yang bertemu secara khusus untuk mencapai tujuan tertentu.

Leonard D. White mengatakannya: administrasi adalah proses yang biasanya ditemukan di semua perusahaan dalam kelompok, baik pemerintah atau swasta, sipil atau militer, besar atau kec

Helbert A. Simon menegaskan yang berikut: dalam arti kata yang luas, manajemen dapat dirumuskan sebagai 
kegiatan kelompok yang bekerja bersama untuk mencapai tujuan bersama.

Definisi ini diperbarui sebagai berikut: Administrasi adalah serangkaian kegiatan penataan untuk pekerjaan utama dan sumber-sumber kegiatan lainnya yang dirancang untuk mencapai tujuan dalam kolaborasi sekelompok orang.

\section{Fungsi-Fungsi Administrasi}

Fungsi administratif dalam suatu organisasi antara lain:

\section{Perencanaan}

Perencanaan yaitu suatu kegiatan administrasi, dimulai dengan pengumpulanpengumpulan data, kemudian setelah data terkumpul dilakukan pemrosesan data, dan terakhir membuat perencanaan.

\section{Organisasi}

Pengorganisasian adalah suatu kegiatan dalam menyusun dan membangun komunikasi kerja antara sesama anggota organisasi, sehingga entitas komersial tercapai.

\section{Koordinasi}

Koordinasi adalah bagian dari fungsi manajemen. Melakukan berbagai kegiatan untuk melakukan dengan baik, menghindari kekacauan, dan kekosongan dari kegiatan yang dilakukan, menghubungkan, bergabung, dan menyesuaikan pekerjaan bawahan, sehingga ada kerja sama terencana, dalam upaya mencapai tujuan organisasi.

\section{Laporan}

Adalah kegiatan memberikan perkembangan atau hasil dari suatu kegiatan, membuat dan memberikan laporan tentang tugas dan fungsi pejabat senior, baik secara lisan maupun tertulis, untuk memperoleh gambaran umum tentang pelaksanaan tugastugas anggota organisasi.

\section{Anggaran}

Anggaran adalah kegiatan perencanaan dalam manajemen keuangan dan anggaran dalam suatu organisasi yang dilakukan secara berkelanjutan.

\section{Penempatan}

Adalah kegiatan yang berkaitan dengan SDM dan sumber-sumber daya lainnya dalam suatu organisasi, mulai dari mempekerjakan pekerja, pengembangan, peralatan dalam organisasi.

\section{Pengarahan atau bimbingan}

Mengarahkan adalah aktivitas berinteraksi dengan dan antar anggota organisasi dalam bentuk memberi orientasi, saran, serta perintah, sehingga tugas tersebut dijalankan dengan tepat, sehingga dapat mencapai tujuan yang telah ditetapkan.Menurut Quible, fungsi pendukung administrasi dalam perkantoran, antara lain yaitu:

Fungsi rutin, yaitu fungsi administrasi kantor yang memerlukan refleksi minimal 
untuk mencakup pengarsipan dan Pengertian Jasa

penggandaan.

Fungsi teknis, yaitu fungsi administratif yang memerlukan pendapat, keputusan, dan keterampilan kantor yang tepat, seperti kemungkinan menggunakan berbagai program aplikasi komputer. Fungsi ini biasanya dilakukan oleh tim administrasi yang merupakan anggota departemen teknologi informasi.

Fungsi analis, yang membutuhkan pemikiran kritis, disertai dengan kemampuan untuk membuat keputusan, bagaimana menyiapkan dan menganalisis laporan dan membuat keputusan pembelian. Fungsi ini biasanya dilakukan oleh manajer yang bertanggung jawab untuk mendukung keputusan yang akan dibuat oleh manajer.

Fungsi interpersonal, fungsi yang membutuhkan evaluasi atau analisis sebagai dasar untuk pengambilan keputusan, serta keterampilan yang terkait dengan orang lain, seperti mengoordinasikan tim proyek. Peran ini biasanya dimainkan oleh tim manajemen sebagai karier sebelum naik menjadi manajer sebuah organisasi.

Fungsi manajemen, yang memerlukan perencanaan, organisasi pengukuran dan motivasi, seperti anggaran dan evaluasi karyawan. Peran ini biaanya dilakukan oleh tim tingkat manajemen yang bertanggung jawab untuk menerapkan sistem dan prosedur administrasi.
Menurut Valarie A. Zeithami dan Mary Jo Bitner (2009: 3), ia menegaskan bahwa jasa adalah kegiatan ekonomi di mana produksi produk dikonsumsi bersamaan dengan produksi dan menawarkan nilai tambah, seperti kesenangan, hiburan, relaksasi dan kesehatan yang tidak berwujud.

Menurut Kotler dan Keller (2009: 410), jasa adalah semua tindakan atau kinerja yang dapat ditawarkan oleh satu pihak ke pihak lain, pada dasarnya tidak berwujud/terlihat dan tidak menghasilkan properti apa pun.

Dengan pendapat ini, penulis menyimpulkan bahwa jasa adalah suatu tindakan dari satu pihak ke pihak lain atau kegiatan yang tidak teraba, dirancang untuk memuaskan kepuasan pelanggan.

Definisi pengiriman Menurut Krismiaji (2013), definisi pengiriman adalah kegiatan mengirim produk ke pelanggan secara efisien dan akurat. Pengertian pengiriman secara umum adalah proses pengiriman produk dari satu bagian ke bagian lain yang dapat memudahkan konsumen

\section{HASIL DAN PEMBAHASAN}

Menurut data yang dikumpulkan di lapangan, disesuaikan dengan rumusan masalah dan tujuan penulisan, serta sesuai 
dengan langkah-langkah dan metode pengumpulan data pada bab sebelumnya, penulis akan membahas prosedur untuk jasa pengiriman di PT TIKI Tangerang: pengiriman barang di PT TIKI Tangerang benar-benar harus dilakukan pada semua karyawan yang berhubungan langsung dengan konsumen. Setiap karyawan harus dapat menjelaskan prosedur atau ketentuan yang ada di perusahaan, sehingga mempermudah konsumen dalam melakukan pengiriman, dengan konsumen mengetahui setiap prosedur yang berlaku di perusahaan maka konsumen akan sangat bijak dalam melakukan transaksi di setiap gerai yang ada di daerah tempat tinggal konsumen dan manfaat yang didapat dari menjelaskan prosedur kepada konsumen, karyawan tidak akan merasa cemas untuk semua pengiriman yang dipercayakan oleh konsumen karena konsumen akan mengirimkan produk sesuai dengan aturan- aturan yang telah diberikan oleh perusahaan untuk meminimalkan penipuan atau kebohongan dengan memberikan informasi tentang pengiriman yang dilakukan karena secara tidak langsung konsumen akan tahu barang mana yang layak dikirim dan mana yang tidak.

Menurut data yang dikumpulkan dari lapangan, dan disesuaikan dengan rumusan masalah dan tujuan penelitian, serta sesuai dengan langkah-langkah pengumpulan data dan metode bab sebelumnya, penulis akan menganalisis prosedur untuk jasa pengiriman di PT TIKI Tangerang: Pengiriman barang ke PT TIKI Tangerang sudah benar dan harus dilakukan untuk semua karyawan yang berhubungan langsung dengan konsumen. Setiap karyawan harus dapat menjelaskan prosedur atau peraturan perusahaan untuk memfasilitasi pemrosesan pengiriman oleh konsumen. Selain itu, konsumen harus terbiasa dengan semua prosedur yang berlaku di perusahaan. Konsumen harus sangat cerdas dalam memilih tempat pengiriman barang yang ada di wilayah tempat mereka tinggal dan memahami manfaat yang dihasilkan. Konsumen mengirim produk sesuai dengan aturan yang ditetapkan oleh perusahaan untuk meminimalkan penipuan atau kebohongan dengan memberikan informasi tentang pengiriman, secara tidak langsung mengetahui barang mana yang memenuhi syarat untuk pengiriman dan mana yang tidak.

Standar operasional prosedur (SOP) yang diterapkan pada perusahaan adalah untuk surat berharga harus diasuransikan dan juga untuk produk elektronik juga harus diasuransikan dan menerima pengemasan kayu, seperti barang- barang penting yang diketahui atau dokumen- dokumen penting, seperti surat tanda nomor kendaraan (STNK) atau bukti kepemilikan kendaraan 
bermotor (BPKB), dokumen- dokumen tersebut harus diasuransikan, karena sesuai dengan aturan dan Standar operasional prosedur (SOP) perusahaan, sehingga, jika ada kerusakan atau kehilangan, konsumen tidak merasa cemas, karena akan ada pergantian sesuai dengan harga penerbitan surat berharga tersebut, dan konsumen tidak dapat mengirim hewan yang dilindungi oleh Negara, serta pengiriman zat atau obat ilegal. Demikian pula, semua produk elektronik yang harus dalam wadah kayu atau memiliki keamanan dan harus diasuransikan, karena keberadaan wadah kayu akan meminimalkan kerusakan yang terjadi selama perjalanan dalam proses pengiriman.

Kendala yang biasanya terjadi dalam menjalankan prosedur administrasi jasa pengiriman barang di PT TIKI Tangerang (1) Konsumen sangat tidak terbuka atas isi dari kiriman, biasanya konsumen ada yang tidak memberikan informasi yang jelas atas kiriman tersebut dikarenakan pengirim menitipkan kirimannya terhadap orang suruhan atau bawahan dengan demikian isi dari kirimannya terkadang berbeda dengan isi yang sebenarnya sehingga jika ada sesuatu yang terjadi terhadap barang tersebut konsumen tidak dapat melakukan pergantian atas kerusakan yang terjadi; (2) Adanya hari libur nasional sehingga terjadi keterlambatan pengiriman, karena dengan adanya tanggal merah, pengiriman akan diprioritaskan untuk holiday service dengan biaya yang berbeda dari biasanya dan untuk pengiriman service regular akan ada penundaan hingga empat hari kerja; (3) Kehilangan resi, jika ini terjadi, akan sulit bagi konsumen untuk melacak status pengiriman karena mereka tidak memiliki bukti nomor pengiriman pada tanda terima, jika ada kehilangan atau kerusakan, konsumen tidak akan dapat membuat klaim terhadap perusahaan; (4) Bencana alam yang biasa terjadi di Kota Tangerang adalah banjir, dengan adanya banjir maka petugas yang melakukan pengiriman tidak dapat berkatifitas seperti biasa, dengan begitu akan banyak sekali penumpukan barang yang terjadi di perusahaan karna kondisi jalan yang tidak mendukung.

\section{PENUTUP}

\section{Kesimpulan}

Berdasarkan hasil diskusi pada bab sebelumnya, penulis dapat menarik kesimpulan sebagai berikut: Standar operasional prosedur (SOP) untuk surat berharga harus diasuransikan dan juga untuk produk elektronik juga harus diasuransikan dan menerima pengemasan kayu sehingga, jika ada kerusakan atau kerugian, konsumen tidak perlu merasa cemas, karena akan ada sesuai dengan harga penerbitan surat berharga tersebut, dan konsumen tidak boleh 
mengirim hewan yang dilindungi oleh Negara dan mengirim zat atau obat terlarang. Demikian pula, semua produk elektronik harus dalam wadah kayu atau memiliki keamanan dan harus diasuransikan, karena keberadaan wadah kayu akan meminimalkan kerusakan yang terjadi selama perjalanan dalam proses pengiriman.

Kendala yang biasanya terjadi dalam menjalankan prosedur administrasi jasa pengiriman barang di PT TIKI Tangerang adalah ada beberapa konsumen yang tidak terlalu terbuka dengan konten pengiriman, adanya hari libur nasional sehingga terjadi keterlambatan pengiriman, kehilangan resi, jika ini terjadi, konsumen akan mengalami kesulitan melacak status pengiriman dan, jika ada kerugian atau kerusakan, konsumen tidak akan dapat mengajukan klaim terhadap perusahaan. Dan kendala berikutnya adalah, jika terjadi bencana alam petugas pengiriman tidak dapat melakukan kegiatan seperti biasa.

Dari uraian di atas, penulis dapat memberikan saran, kualitas administrasi umum yang diberikan PT Citra Van Titipan Kilat kepada konsumen tidak diragukan lagi sangat bagus. Namun, ada beberapa poin yang harus ditingkatkan oleh PT TIKI Tangerang mengenai kualitas pengiriman, yaitu: keandalan (reliability); Saat ini adalah era digital, oleh karena itu, PT TIKI
Tangerang harus dapat meningkatkan layanannya melalui smart mobile, untuk memudahkan konsumen menemukan kiriman tanpa harus datang atau menghubungi layanan pelanggan hanya untuk Cari tahu status pengiriman. Dengan kemudahan pelanggan menggunakan smart mobile, kepuasan pelanggan akan meningkat.

\section{DAFTAR PUSTAKA}

\section{Sumber Buku}

Fajar laksana. (2019). Praktis Memahami Manajeman Pemasaran. Sukabumi. Khalifa Mediatama

Gerson, Richard f. (2014). Mengukur Kepuasan Pelanggan. Jakarta: PPM

Herdiansyah. (2011). Kualitas Pelayan Publik. Jogjakarta: Gava Media

Krimisaji, (2015). Sistem Informasi Akuntansi, Jogjakarta, Yayasan Keluarga Pahlawan Negara.

Kotler, dan Keller. (2012). Manajeman

Pemasaran Edisi Kedua, Jakarta: Erlangga.

Sutarman. (2017). Dasar Dasar Manageman Logistik. Bandung: Refika Aditama

Tjiptono, Fandi. (2012). Pemasaran Jasa, Prisnsip, Penerapan, Dan Penelitian.

Wijaya, Tony. (2011). Manageman Kualitas Jasa.

Jakarta Barat: INDEKS

\section{$\underline{\text { Sumber Internet }}$}

Junaedi, Edi. (2019, Vol. 6 No. 1) diakses dari:http://openjournal.unpam.ac.id/inde x.php/Sekretaris/article/view/2470/1951

Monuments. In Encyclopedia of local history. (pp. 363-364) Lanham, MD: AltaMira Press. 


\section{Surat Kabar Cetak}

Rosenberg, G. (1997, March 31). Electronic discovery proves an effective legal weapon. The New York Times, p. D5.

\section{Surat Kabar Online}

Rosenberg, G. (1997, March 31). Electronic discovery proves an effective legal weapon. The New York Times. Diakses dari http://www.nytimes.com

\section{Majalah Cetak}

Tumulty, K. (2006, April). Should they stay or should they go? Time, 167(15), 3-40.

\section{Majalah Online}

Tumulty, K. (2006, April). Should they stay or should they go? Time, 167(15). Diakses dari http://content.time.com/time/magazine /article/0,9171,1179361,00.html 